\title{
Metal Bioavailability in Contaminated Estuarine Sediments from a Highly-Impacted Tropical Bay
}

\author{
Monte, C. N.; Rodrigues, A. P. C.; Freire, A. S.; Santelli, R. E.*; Machado, W. \\ Rev. Virtual Quim., 2017, 9 (5), 2007-2016. Data de publicação na Web: 17 de outubro de 2017 \\ http://rvq.sbq.org.br \\ Biodisponilidade de Metais em Sedimentos Estuarinos de uma Baía Tropical \\ Altamente Impactada
}

Resumo: O objetivo deste estudo é avaliar a possível variabilidade de metais-traço ( $\mathrm{Cd}, \mathrm{Cu}, \mathrm{Pb}$ e $\mathrm{Zn}$ ) e a biodisponibilidade ao longo do canal principal de um estuário tropical altamente eutrofizado (estuário do Rio Iguaçu, Baía de Guanabara, Brasil). Concentrações de metais potencialmente biodisponíveis (solúveis em $1 \mathrm{~mol} \mathrm{~L}^{-1} \mathrm{HCl}$ ) e concentrações de metais fortemente ligados ao sedimento (solúveis em $\mathrm{HNO}_{3}$ concentrado) foram sequencialmente extraídos e determinados por Espectrometria de Emissão Ótica com Plasma Indutivamente Acoplado (ICP OES). Estes sedimentos, geralmente apresentaram elevadas concentrações de metais-traço associadas à fração fracamente ligada, enquanto o $\mathrm{Zn}$ foi o metal mais biodisponível (aproximadamente 83\% das concentrações de $Z n$ foram encontradas na fração fracamente ligada aos sedimentos), enquanto o Cu mostrou uma grande heterogeneidade na proporção entre a frações fracamente e fortemente ligadas aos sedimentos. A estratégia de amostragem empregada combina resultados de sedimentos coletados ao longo e transversalmente ao canal estuarino, evidenciando que o cuidado é necessário quando apenas um único transecto de amostragem é usado em canais estuarinos, particularmente para metais sensíveis a mudanças no fracionamento geoquímico durante o transporte e redistribuição do sedimento, como foi evidenciado para o Cu neste trabalho.

Palavras-chave: Metal; biodisponibilidade; geoquímica.

\begin{abstract}
The aim of this study is to assess possible spatial variability of trace metal ( $\mathrm{Cd}, \mathrm{Cu}, \mathrm{Pb}$ and $\mathrm{Zn}$ ) bioavailability along the main channel of a highly eutrophic tropical estuary (Iguaçu River estuary, Guanabara Bay, Brazil). Metal potentially-bioavailable concentrations (soluble in $1 \mathrm{~mol} \mathrm{~L}^{-1} \mathrm{HCl}$ ) and strongly-bound concentrations (soluble in concentrated $\mathrm{HNO}_{3}$ ) were sequentially extracted and determined by a Coupled Plasma Optical Emission Spectrometry (ICP OES). These sediments generally have high trace metal contents associated to weakly-bound fractions, while $\mathrm{Zn}$ was the most bioavailable metal (approximately $83 \%$ of Zn concentrations were weakly-bound to sediments) while $\mathrm{Cu}$ showed the greatest heterogeneity of proportion between weakly- and strongly-bound fractions. The employed sampling strategy combined results from sediments taken along and across the estuarine channel, evidencing that care is required when using only a single sampling transect along estuarine channels, particularly for metals sensitive to changes in geochemical partitioning during sediment transport and redistribution, as evidenced by the $\mathrm{Cu}$ concentrations in this work.
\end{abstract}

Keywords: Metal; bioavailability; geochemistry.

\footnotetext{
* Universidade Federal do Rio de Janeiro, Instituto de Química, Departamento de Química Analítica, Campus Ilha do Fundão, 21941-909, Rio de Janeiro- RJ, Brazil.

Msantelli@iq.ufri.br

DOI: $\underline{10.21577 / 1984-6835.20170119}$
}

Rev. Virtual Quim. |Vol 9| |No. 5 | |2007-2016| 


\title{
Metal Bioavailability in Contaminated Estuarine Sediments from a Highly-Impacted Tropical Bay
}

\author{
Christiane do N. Monte, ${ }^{a, b}$ Ana Paula de C. Rodrigues, ${ }^{a}$ Aline S. Freire, ${ }^{c}$ \\ Ricardo E. Santelli, ${ }^{\mathrm{c} *}$ Wilson Machado ${ }^{\mathrm{b}}$ \\ a Universidade Federal Federal Fluminense, Instituto de Química, Departamento de \\ Geoquímica, Campus do Valonguinho, CEP 24020-150, Niterói-RJ, Brazil.

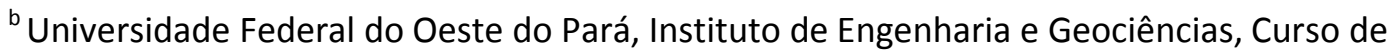 \\ Geologia, Campus Tapajós, CEP 68040-255, Santarém- PA, Brazil. \\ ' Universidade Federal do Rio de Janeiro, Instituto de Química, Centro de Tecnologia, Cidade \\ Universitária, CEP 21941-909, Rio de Janeiro-RJ, Brazil.
}

* santelli@iq.ufrj.br

Recebido em 10 de outubro de 2017. Aceito para publicação em 10 de outubro de 2017

\section{Introduction}

\section{Material and Methods}

2.1. Sampling

2.2. Metal Concentration Determination and Data Treatment

\section{Results and Discussion}

\section{Conclusions}

\section{Introduction}

The combined impact of eutrophication and contamination by toxic metals has been unfortunately frequent in many urbanized and industrialized coastal regions, imposing increasing concerns on environmental and human health. As observed in many developing countries, the Brazilian coast is affected by these anthropogenic impacts, as has been reported for the bays more economically important in this region, which are affected by effluents from urban and industrial areas, besides frequently intense harbor activities. ${ }^{1-4}$ An example of highly impacted bay in Brazil is Guanabara Bay, one of largest bays in the country (with an area of $381 \mathrm{~km}^{2}$ ), which receives the sewage input from the Rio de Janeiro metropolitan area, besides large industrial centers. ${ }^{5}$

In the western region of Guanabara Bay, the Iguaçu River drainage basin is among the more heavily industrialized within the bay area. ${ }^{6}$ This river contributes to the emission of substantial organic and inorganic loads into the bay due to sewage loading, ${ }^{7}$ while the margins near the river mouth host an old landfill (the larger garbage landfill of Latin America, closed in 2012, the Gramacho Metropolitan Landfill) and an oil refinery. A mass balance study performed for some 
metals transported in the water column of the Iguaçu estuary concluded that its affluent Sarapuí River is the major source of trace metals for this system, ${ }^{8}$ while the landfill has been also indicated as an important trace metal source to the bay. ${ }^{9}$ However, this estuary receives trace metals input from other rivers in the western Guanabara Bay region, along with tidal transport. ${ }^{7}$ Previous work have also demonstrated the eutrophic nature of the Iguaçu estuary, showing elevated dissolved nutrient loading in surface waters (e.g., $225.3 \pm 7.9 \mu \mathrm{M} \mathrm{NH}_{4}{ }^{+}$). ${ }^{10}$ Estimates of metal bioavailability in sediment pore water within two sampling stations in this estuarine area was also performed previously, based on acid-volatile (AVS) equilibrium-partitioning approaches. ${ }^{11,12}$

Despite the relatively large number of studies in this estuarine system, there is no previous work on the spatial variability of the potential trace metal bioavailability within the sediment solid phase within this heavily impacted estuary. The present work aimed to evaluate the potential bioavailability of known metal contaminants $(\mathrm{Cd}, \mathrm{Cu}, \mathrm{Pb}$ and $\mathrm{Zn}$ ) in the estuarine sediments of Iguaçu River (Guanabara Bay, Rio de Janeiro State), using a two-step geochemical partitioning approach. The hypothesis tested in this study is that the solid-phase bioavailability of different trace metals will vary differently along and across the estuarine channel, which may have implications for the consistency of future sediment sampling strategies.

\section{Material and Methods}

\subsection{Sampling}

The twelve surface sediment samples were obtained using a van Veen sampler. Samples were sealed in plastic bags and stored refrigerated until laboratorial analyses. Sediment sampling was carried out in September 2010 (end of dry season), during low tide along four transects (with 3 sampling stations per transect), which were perpendicular to the estuarine channel. As represented in the Figure 1, sampling stations named with an " $M$ " represent middle channel, while the other stations (those named as " $D$ " were located on the right side of the channel and those named as " $E$ " on the left side of the channel) represent channel border conditions.

\subsection{Metal concentration determination and data treatment}

The sediment samples were dried at $<40^{\circ} \mathrm{C}$ and homogenized prior to perform the sequential extraction procedure. The extractions of potentially-bioavailable (weakly-bound phase) and strongly-bound fractions were performed sequentially. The potentially-bioavailable fraction was obtained by agitation of sediment subsamples in $40 \mathrm{~mL}$ of a $1 \mathrm{~mol} \mathrm{~L}^{-1} \mathrm{HCl}$ solution, during 16h. After this extraction, the sediment suspensions were centrifuged, the supernatant was separated and filtered for metal concentration analyses and the processed sediment was washed three times with distilled water to remove residues of the acid solution previously used. This procedure was described elsewhere, ${ }^{13,14}$ as adapted from a previous work. ${ }^{15}$ The use of $1 \mathrm{~mol} \mathrm{~L}^{-1}$ $\mathrm{HCl}$ solution to extract potentiallybioavailable metal concentrations has been widely disseminated in the literature, corresponding to the called "reactive phases", such as metals adsorbed onto sediment particles, metal carbonates, amorphous and poorly-crystalized metal sulfides, metal bound to hydrolysable organic matter and metal oxides. ${ }^{16}$ For example, comparisons of metal bioavailability assessments using acetic acid $0.11(\mathrm{v} / \mathrm{v})$, acetic acid $25 \%$ and $1 \mathrm{~mol} \mathrm{~L}^{-1} \mathrm{HCl}$, with and without trypsin and pepsin extractions, to simulate the digestive system of marine organisms, have indicated the $1 \mathrm{~mol} \mathrm{~L}^{-1} \mathrm{HCl}$ extraction as the most efficient procedure. ${ }^{17}$ 


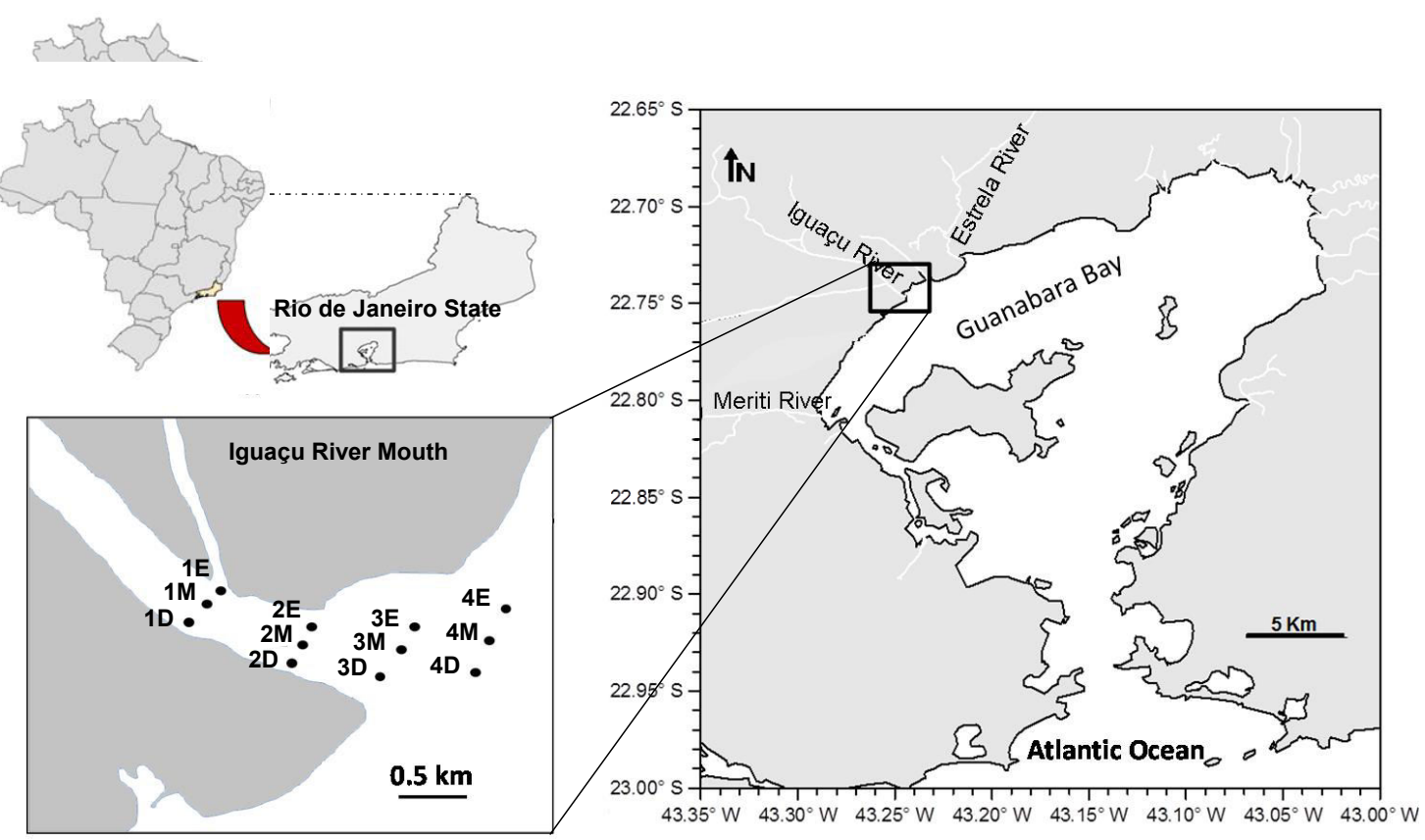

Figure 1. Surface sediment sampling stations in the estuary of the Iguaçu River, Guanabara Bay - RJ, Brazil

After drying the sediments previously extracted from the weakly-bound fraction at $40^{\circ} \mathrm{C}$, these sediments were homogenized and submitted to EPA 3051A extraction method. ${ }^{18}$ In this procedure, $0.5 \mathrm{~g}$ of dried samples was submitted to a microwave radiation-assisted extraction in $10 \mathrm{~mL}$ of $\mathrm{HNO}_{3}$ (concentrated). Metal concentration analyses in both extracts (diluted $\mathrm{HCl}$ and concentrated $\mathrm{HNO}_{3}$ ) were performed by Inductively Coupled Plasma Optical Emission Spectrometry (ICP OES). In order to verify the accuracy of the methods, a certified reference material was analyzed (CRM NIST 2782). The results from this analysis and the analytical detection limits are given in Table 1.

Table 1. Concentrations of trace metals in certified reference material (NIST CRM 2782) and the respective detection limits (DL)

\begin{tabular}{ccccc}
\hline & $\mathrm{Cd}$ & $\mathrm{Cu}$ & $\mathrm{Pb}$ & $\mathrm{Zn}$ \\
\hline DL $\left(\mathrm{mg} \mathrm{kg}^{-1}\right)$ & 0.01 & 0.01 & 0.03 & 0.31 \\
NIST CRM 2782 & & & & \\
Measured $\left(\mathrm{mg} \mathrm{kg}^{-1}\right)$ & - & 2.43 & 529 & 1172 \\
Certified $\left(\mathrm{mg} \mathrm{kg}^{-1}\right)$ & $\mathrm{NA}$ & $2.435 \pm 0.47$ & $554 \pm 36$ & $1167 \pm 57$ \\
Recovery $(\%)$ & $\mathrm{NA}$ & 99.7 & 95.5 & 100
\end{tabular}

NA, not available.

Trace metal concentrations were determined after extractions in diluted $\mathrm{HCl}$ and concentrated $\mathrm{HNO}_{3}$ are noted as " $\mathrm{HCl}$ $\mathrm{Me}$ " and " $\mathrm{HNO}_{3}-\mathrm{Me}^{\prime}$, respectively. The sums 
of results from these two sequential extractions are noted as " $\Sigma \mathrm{Me}^{\circ}$. The percent of $\mathrm{HCl}-\mathrm{Me}$ in relation to $\Sigma \mathrm{Me}$ (noted as $\% \mathrm{HCl}$ $\mathrm{Me}$ ) was adopted as the relative estimate of metal bioavailability. ${ }^{13,14}$ Sediment sand content was estimated by using a CILAS particle-size meter.

Statistical tests were performed using the software Statistica (Statsoft ${ }^{\circledR}$ ) to evaluate possible correlations (Spearman test) and potential differences between datasets (Mann-Whitney $U$ test). A significance level of 0.05 was deemed accepted.

\section{Results and Discussion}

The Table 2 presents the obtained metal concentrations, while... The average metal concentrations occurred in the following order: $\mathrm{Zn}>\mathrm{Cu}>\mathrm{Pb}>\mathrm{Cd}$. Lower metal concentrations and metal bioavailability estimates were consistently observed in the middle channel stations (Figure 2). MannWhitney $\mathrm{U}$ tests showed that all $\Sigma \mathrm{Me}$ and $\% \mathrm{HCl}-\mathrm{Me}$ data presented significant differences between middle channel (stations " $\mathrm{M}$ ") and border (stations " $\mathrm{E}$ " and " $\mathrm{D}$ "). These differences could not be explained by sediments grain size variability, since sand was detected only in two sampling stations (stations $1 \mathrm{M}$ and 3D showed 14 and 19\% sand, respectively).

In general, the weakly-bound phases corresponded to large fractions of the recovered metal concentrations ( $(\mathrm{Me})$ along the study area, with the \% $\mathrm{HCl}-\mathrm{Me}$ ranging from 27 to $67 \%(\mathrm{Cd}), 19.5$ to $79.5 \%(\mathrm{Cu}), 55.8$ to $81.1 \%(\mathrm{~Pb})$ and 64.6 to $92.9 \%(\mathrm{Zn})$. Spearman rank correlation tests showed that all $\Sigma \mathrm{Me}$ of different metals were significantly correlated $\left(r_{s}>0.68 ; p<0.05\right)$, except for $\Sigma C d$ and $\Sigma \mathrm{Cu}\left(r_{s}=0.44 ; p<0.05\right)$, suggesting a general distribution trend similarity for the metal contaminants. Significant correlations were also found for all \% $\mathrm{HCl}-\mathrm{Me}$ data from different metals $\left(r_{s}>0.65 ; p<0.05\right)$, indicating that spatial variability in the bioavailability trends are also similar.
In the Brazilian jurisdiction, Sediment Quality Guidelines (SQGs) are established for the studied trace metals ( $\mathrm{Cd}, \mathrm{Cu}, \mathrm{Pb}$ and $\mathrm{Zn}$ ), as routinely used for the licensing process of dredging activities. ${ }^{19}$ This legislation adopted the SQG levels proposed by Long et al., ${ }^{20}$ where the Level 1 correspond to the ERL (Effects Range Low) and their Level 2 correspond to the ERM (Effects Range Median) (Table 3). The $\mathrm{HCl} 1 \mathrm{~mol} \mathrm{~L}^{-1}$ extractable trace metals concentrations (Table 2) were mostly below the SQG, with only the sampling station $1 \mathrm{D}$ showing a $\mathrm{HCl}-$ $\mathrm{Cu}$ level above the ERL. However, some samples presented $\Sigma \mathrm{Cu}, \Sigma \mathrm{Pb}$ and $\Sigma \mathrm{Zn}$ concentrations (Table 2) above the respective ERL values (Table 3 ). In these cases, the Brazilian legislation indicates the necessity of further studies, including ecotoxicological analysis, as used to investigate risks to aquatic biota.

Many factors can influence the metal solid phase partitioning between more reactive (weakly-bound) and more refractory (strongly-bound) geochemical fractions. For example, redox conditions may regulate the mobility of trace metals, such as $\mathrm{Cu}, \mathrm{Pb}$ and $\mathrm{Zn},{ }^{21,22}$ as the mineralization of organic matter may also affect the metal geochemical partitioning. ${ }^{23,24}$ In the study area, the susceptibility of the trace metal bioavailability could be affected by biogeochemical processes as associated to the sediment position in the estuarine channel. A significant spatial variability in metal concentrations have also been reported for different topographic positions in the tidal channel beds elsewhere, ${ }^{25,26}$ which may associated to the sediment susceptibility to resuspension and redistribution processes and changes in the physicochemical conditions.

Copper showed the highest percentages of bioavailable fractions and the highest variability in these results. This metal is the most prominent case of bioavailability contrast between middle and border stations (Table 2 and Figure 2). This may be related to a larger oxidation of refractory reduced $\mathrm{Cu}$ binding compounds in border stations. For 
example, $\mathrm{Cu}$ has geochemical affinity to $\mathrm{FeS}_{2}$ (pyrite) that is the predominant metal sulfide in coastal sediments, but pyrite may be susceptible to oxidation if exposed to oxidizing conditions. ${ }^{15}$ After a resuspension experiment of sediments from one sampling station located in the Iguaçu river estuary, $\mathrm{Cu}$ presented a change of $\mathrm{HCl}$-extractable concentrations from seven times lower to two times higher values than the ERL value, which was explained by a transition from a strongly-bound $\mathrm{Cu}$ fraction $\left(\mathrm{FeS}_{2}\right)$ to a $\mathrm{HCl}$ - extractable (probably metal oxide-bound) $\mathrm{Cu}$ fraction. ${ }^{13}$ However, a lower susceptibility to be affected by these processes is suggested for the other studied metals, since $\mathrm{Cd}, \mathrm{Pb}$ and $\mathrm{Zn}$ generally have lower affinity to be incorporated into $\mathrm{FeS}_{2}$, and tend to form their own metal monosulfides. ${ }^{27,28}$ Therefore, the interpretations of data obtained along and across estuarine channels should to take into account the geochemical behaviors of different metal in response topographic position of sampling stations.

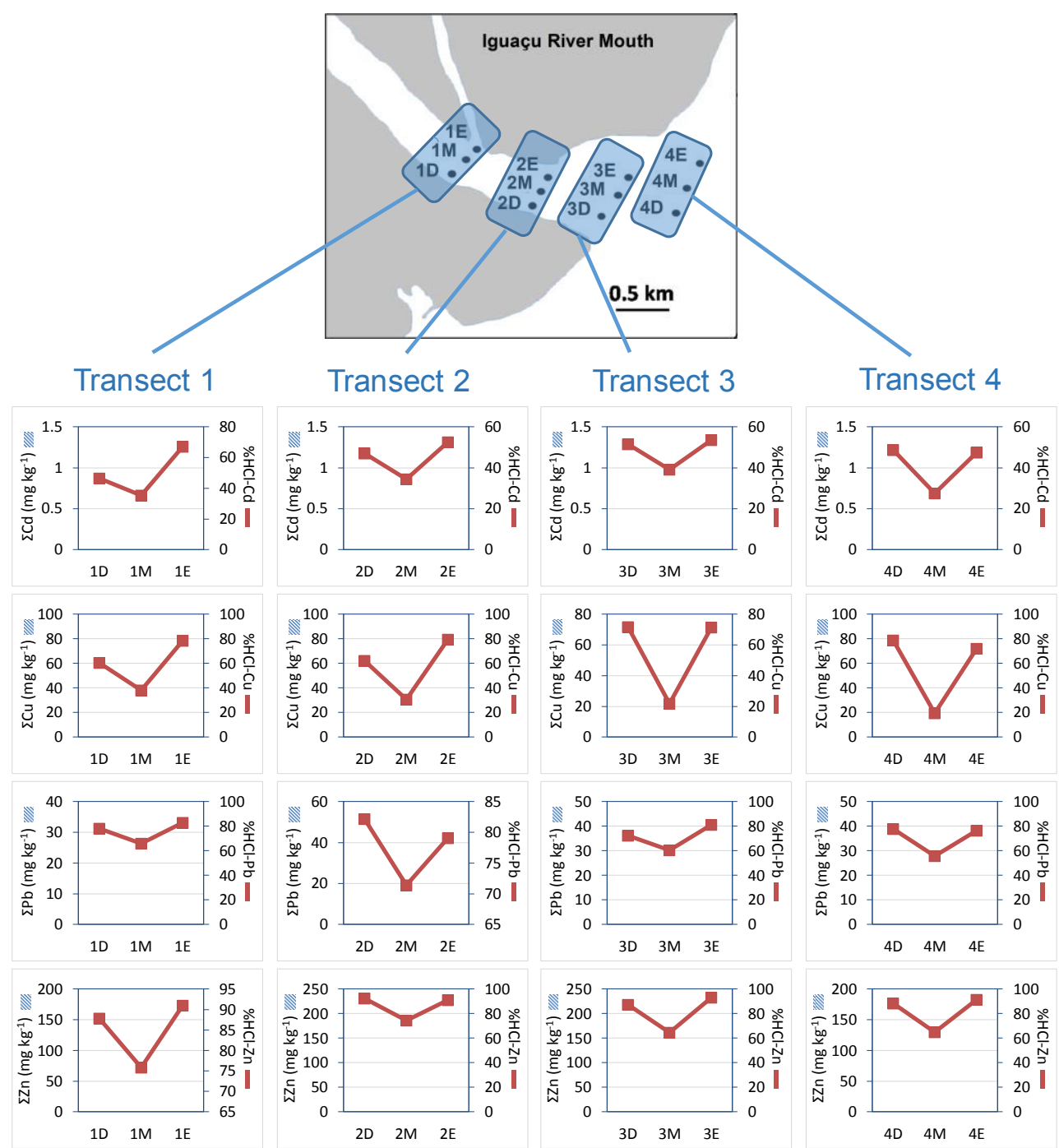

Figure 2. Spatial variability of the sums the metal (Me) concentrations from the two sequential extractions steps $(\Sigma \mathrm{Me})$ and the percent of $\mathrm{HCl}$-soluble concentrations in relation to $\Sigma \mathrm{Me}$ (\% $\mathrm{HCl}-\mathrm{Me})$ 
Table 2. Trace metal concentrations determined after the procedures to obtain $\mathrm{HCl}$ extractable $(\mathrm{HCl}-\mathrm{Me})$ and $\mathrm{HNO}_{3}$-extractable $\left(\mathrm{HNO}_{3}-\mathrm{Me}\right)$ geochemical factions, and the sums of results from these two sequential extractions $(\Sigma \mathrm{Me})$

\begin{tabular}{|c|c|c|c|c|c|}
\hline Extraction & Sample & $\mathrm{Cd}\left(\mathrm{mg} \mathrm{kg}^{-1}\right)$ & $\mathrm{Cu}\left(\mathrm{mg} \mathrm{kg}^{-1}\right)$ & $\mathrm{Pb}\left(\mathrm{mg} \mathrm{kg}^{-1}\right)$ & $\mathrm{Zn}\left(\mathrm{mg} \mathrm{kg}^{-1}\right)$ \\
\hline \multirow[t]{14}{*}{$\mathrm{HCl}-\mathrm{Me}$} & $1 \mathrm{D}$ & 0.60 & 30.0 & 29.5 & 118.3 \\
\hline & $1 \mathrm{M}$ & 0.35 & 5.4 & 12.4 & 40.0 \\
\hline & $1 \mathrm{E}$ & 0.76 & 41.4 & 29.6 & 147.1 \\
\hline & $2 \mathrm{D}$ & 0.66 & 58.4 & 42.3 & 187.6 \\
\hline & $2 M$ & 0.35 & 4.4 & 17.0 & 43.3 \\
\hline & $2 \mathrm{E}$ & 0.65 & 52.3 & 37.2 & 181.7 \\
\hline & $3 D$ & 0.49 & 39.8 & 28.2 & 147.5 \\
\hline & $3 M$ & 0.38 & 2.9 & 10.6 & 30.7 \\
\hline & $3 \mathrm{E}$ & 0.74 & 57.3 & 37.8 & 216.1 \\
\hline & $4 \mathrm{D}$ & 0.52 & 44.2 & 31.3 & 143.1 \\
\hline & $4 M$ & 0.22 & 1.9 & 8.3 & 27.9 \\
\hline & $4 \mathrm{E}$ & 0.53 & 47.8 & 30.8 & 161.8 \\
\hline & Average & 0.52 & 32.2 & 26.3 & 120.4 \\
\hline & SD & 0.17 & 22.4 & 11.4 & 67.5 \\
\hline \multirow{14}{*}{$\mathrm{HNO}_{3}-\mathrm{Me}$} & $1 \mathrm{D}$ & 0.69 & 19.6 & 8.4 & 16.4 \\
\hline & $1 \mathrm{M}$ & 0.64 & 8.9 & 6.5 & 12.7 \\
\hline & $1 \mathrm{E}$ & 0.37 & 11.4 & 6.2 & 14.6 \\
\hline & $2 \mathrm{D}$ & 0.75 & 35.8 & 9.2 & 15.4 \\
\hline & $2 M$ & 0.66 & 9.9 & 6.8 & 14.9 \\
\hline & $2 \mathrm{E}$ & 0.59 & 13.5 & 9.9 & 18.3 \\
\hline & $3 D$ & 0.46 & 15.8 & 10.8 & 21.3 \\
\hline & $3 M$ & 0.59 & 10.3 & 7.0 & 16.8 \\
\hline & $3 E$ & 0.64 & 23.1 & 8.8 & 16.6 \\
\hline & $4 \mathrm{D}$ & 0.55 & 11.9 & 9.0 & 18.7 \\
\hline & $4 M$ & 0.59 & 7.9 & 6.6 & 15.2 \\
\hline & $4 \mathrm{E}$ & 0.59 & 18.6 & 9.4 & 15.7 \\
\hline & Average & 0.59 & 15.5 & 8.2 & 16.4 \\
\hline & SD & 0.10 & 7.9 & 1.6 & 2.2 \\
\hline \multirow[t]{14}{*}{$\Sigma \mathrm{Me}\left(\mathrm{HCl}+\mathrm{HNO}_{3}\right)$} & $1 \mathrm{D}$ & 1.29 & 49.6 & 37.8 & 135 \\
\hline & $1 \mathrm{M}$ & 0.99 & 14.3 & 18.8 & 53 \\
\hline & $1 \mathrm{E}$ & 1.13 & 52.8 & 35.8 & 162 \\
\hline & $2 \mathrm{D}$ & 1.41 & 94.2 & 51.5 & 203 \\
\hline & $2 M$ & 1.01 & 14.3 & 23.8 & 58 \\
\hline & $2 \mathrm{E}$ & 1.24 & 65.8 & 47.1 & 200 \\
\hline & $3 D$ & 0.94 & 55.5 & 39.1 & 169 \\
\hline & $3 M$ & 0.96 & 13.2 & 17.6 & 48 \\
\hline & $3 E$ & 1.37 & 80.4 & 46.6 & 233 \\
\hline & $4 \mathrm{D}$ & 1.06 & 56.1 & 40.3 & 162 \\
\hline & $4 \mathrm{M}$ & 0.81 & 9.8 & 14.8 & 43 \\
\hline & $4 \mathrm{E}$ & 1.12 & 66.4 & 40.2 & 177 \\
\hline & Average & 1.11 & 47.7 & 34.5 & 137 \\
\hline & SD & 0.18 & 28.5 & 12.5 & 68 \\
\hline
\end{tabular}

SD, standard deviation. 
Table 3. Trace metals concentrations adopted as Sediment Quality Guidelines in Brazil (CONAMA 454/2012), derived from Long et al. ${ }^{20}$

\begin{tabular}{ccc}
\hline Metals & Level $1\left(\mathrm{mg} \mathrm{kg}^{-1}\right)$ & Level $2\left(\mathrm{mg} \mathrm{kg}^{-1}\right)$ \\
\hline Cadmium & 1.2 & $7.2^{*}$ \\
Copper & 34 & 270 \\
Lead & 46.7 & 210 \\
Zinc & 150 & 410 \\
\hline
\end{tabular}

*Environmental Canada and Ministère du Développement durable, de l'Environnement et des Parcs du Québec. Criteria for the Assessment of Sediment Quality in Quebec and Application Frameworks: Prevention, Dredging and Remediation. ${ }^{19}$

\section{Conclusions}

In the study area, sedimentary trace metal concentrations were generally highly associated with weakly-bound geochemical fractions. Zinc was the most bioavailable metal (nearly $83 \%$ of $\mathrm{Zn}$ concentrations were weakly-bound to sediments, on average). Copper showed the largest heterogeneity in the proportion between weakly- and strongly-bound fractions, probably in response to its larger susceptibility to change its geochemical partitioning due to refractory Fe sulfide (pyrite) conversion into reactive oxyhydroxides. The results derived from sediments taken along and across the estuarine channel evidenced that care is required when using only a single sampling transect along estuarine channels. This may be particularly important for metals sensitive to changes in the geochemical partitioning during sediment transport and redistribution, as is the case for $\mathrm{Cu}$ in the estuary of this work. However, more evaluations of contrasting sedimentary conditions influencing the behavior of trace metals are recommended to better understand the heterogeneities observed in this preliminary study.

\section{Acknowledgements}

The authors would like to thank to the Rio de Janeiro State Research Foundation (FAPERJ) and the Brazilian Research Council (CNPq) for the financial support. Ana Paula C. Rodrigues thanks the grant from PNPD/CAPES for her postdoctoral project.

\section{References}

${ }^{1}$ Abessa, D. M. S.; Carr, R. S.; Rachid, B. R. F.; Sousa, E. C. P. M.; Hortelani, M. A.; Sarkis, J. E. Influence of a Brazilian sewage outfall on the toxicity and contamination of adjacent sediments. Marine Pollution Bulletin 2005, 50, 875. [CrossRef]

${ }^{2}$ Covelli, S.; Protopsalti, I.; Acquavita, A.; Sperle, M.; Bonardi, M.; Emili, A. Spatial variation, speciation and sedimentary records of mercury in the Guanabara Bay (Rio de Janeiro, Brazil). Continental Shelf Research 2012, 35, 29. [CrossRef]

${ }^{3}$ Baptista-Neto, J. A.; Peixoto, T. C. S.; Smith, B. J.; Mcalister, J. J.; Patchineelam, S. M.; Patchineelam, S. R.; Fonseca, E. M. Geochronology and heavy metal flux to Guanabara Bay, Rio de Janeiro state: a preliminary study. Anais da Academia Brasileira de Ciências 2013, 85, 1317. [CrossRef] 
${ }^{4}$ Andrade, R. L. B.; Hatje, V.; Masqué, P.; Zurbrick, C. M.; Boyle, E. A.; Santos, W. P. C. Chronology of anthropogenic impacts reconstructed from sediment records of trace metals and $\mathrm{Pb}$ isotopes in Todos os Santos Bay (NE Brazil). Marine Pollution Bulletin 2017, In press. [CrossRef] [PubMed]

${ }^{5}$ Kjerfve, B.; Ribeiro, C. H. A.; Dias, G. T. M.; Filippo, A. M.; Quaresma, V. S. Oceanographic characteristics of an impacted coastal bay: Baía de Guanabara, Rio de Janeiro, Brazil. Continental Shelf Research 1997, 17, 1609. [CrossRef]

${ }^{6}$ JICA. Japan International Cooperation Agency. The study on management and improvement of the environmental conditions of Guanabara Bay of Rio de Janeiro, The Federative Republic of Brazil ( $p$. 412). Rio de Janeiro, RJ: JICA and the State Secretariat of Environment and Urban Development, 2003.

${ }^{7}$ Carvalho, M. F.; Machado, W.; Santelli, R. E.; Maddock, J. E. Relationship of Metal Contaminants with Acid-Volatile Sulphides (AVS) in Tropical Estuarine Sediments: Potential Influence on Metal Distribution and Bioavailability. In Environmental Geochemistry in Tropical and Subtropical Environments 2004. Springer Verlag. 392 pp. [CrossRef]

${ }^{8}$ Silveira, R. P.; Rodrigues, A. P. C.; Santelli, R. E.; Cordeiro, R. C.; Bidone, E. D. Mass balance in the monitoring of pollutants in tidal rivers of the Guanabara Bay, Rio de Janeiro, Brazil. Environmental Monitoring and Assessment 2011, 181, 165. [CrossRef]

${ }^{9}$ Carvalho, M. F.; Maddock, J. E. L.; Santelli, R. E.; Moscatelli, M.; Vital, N. A. Availability and toxicity of metals in Sarapui River, Guanabara Bay, RJ - Brazil, bordered by an urban landfill and under influence of an oil refinery. Abstracts of Environmental Geochemistry in Tropical Countries, Nova Friburgo, Brazil, 1999.

${ }^{10}$ Brandini, N.; Rodrigues, A. P. C.; Abreu, I. M.; Cotovicz Jr, L. C.; Knoppers, B. A.; Machado, W. Nutrient behavior in a highlyeutrophicated tropical estuarine system. Acta Limnologica Brasiliensis 2016, 28, e-21. [CrossRef]
${ }^{11}$ Machado, W.; Carvalho, M. F.; Santelli, R. E.; Maddock, J. E. L. Reactive sulfides relationship with metals in sediments from an eutrophicated estuary in Southeast Brazil. Marine Pollution Bulletin 2004, 49, 89. [CrossRef]

${ }^{12}$ Machado, W.; Villar, L. S.; Monteiro, F. F.; Viana, L. C. A.; Santelli, R. E. Relation of acidvolatile sulfides (AVS) with metals in sediments from eutrophicated estuaries: Is it limited by metal-to-AVS ratios? Journal of Soils and Sediments 2010, 10, 1606. [CrossRef]

${ }^{13}$ Machado, W; Rodrigues, A. P. C.; Bidone, E. D.; Sella, S. M.; Santelli, R. E. Evaluation of Cu potential bioavailability changes upon coastal sediment resuspension: an example on how to improve the assessment of sediment dredging environmental risks. Environmental Science and Pollution Research 2011, 18, 1033. [CrossRef]

${ }^{14}$ Monte, C. N.; Rodrigues, A. P. C.; Cordeiro, R. C.; Freire, A. S.; Santelli, R. E.; Machado, W. Changes in $\mathrm{Cd}$ and $\mathrm{Zn}$ bioavailability upon an experimental resuspension of highly contaminated coastal sediments from a tropical estuary. Sustainable Water resources management 2015, 1, 335. [CrossRef]

${ }^{15}$ Morse, J. W. Interactions of trace metals with authigenic sulfide minerals: implications for their bioavailability. Marine Chemistry 1994, 46, 1. [CrossRef]

${ }^{16}$ Huerta-Diaz, M. A.; Delgadillo-Hinojosa, F.; Otero, X. L.; Segovia-Zavala, J. A.; HernándezAyon, J. M.; Galindo-Bect, M. S.; AmaroFranco, E. Iron and trace metals in microbial mats and underlying sediments: results from Guerrero Negro Saltern, Baja California Sur, Mexico. Aquatic Geochemistry 2011, 17, 603. [CrossRef]

${ }^{17}$ Peña-Icart, M.; Mendiguchia, C.; Villanueva-Tagle, M. E.; Pomares-Alfonso, $M$. S.; Moreno, C. Revisiting methods for the determination of bioavailable metals in coastal sediments. Marine Pollution Bulletin 2014, 89, 67. [CrossRef]

${ }^{18}$ USEPA - United State Environmental Protection Agency. Microwave assisted acid digestion of sediments, sludges, soils and oils. Method 3051. 2007. [Link] 
${ }^{19}$ CONAMA - Conselho Nacional do Meio Ambiente. Procedures for the evaluation of dredging materials in Brazilian jurisdictional waters. Resolution \#454/2012. Diário Oficial da República Federativa do Brasil, Brasília (in Portuguese). [Link]

${ }^{20}$ Long, E. R.; Macdonald, D. D.; Smith, S. L.; Calder F. D. Incidence of adverse biological effects within ranges of chemical concentrations in marine and estuarine sediments. Environmental Management 1995, 19, 81. [CrossRef]

${ }^{21}$ Clark, M. W.; McConchie, D. M.; Lewis, D. W.; Saenger, P. Redox stratification and heavy metal partitioning in Avicenniadominated mangrove sediments: a geochemical model. Chemical Geology 1998, 149, 147. [CrossRef]

${ }^{22}$ Caplat, C.; Texier, H.; Barillier, D.; Lelievre, C. Heavy metals mobility in harbor contaminated sediments: the case of Port-enBessin. Marine Pollution Bulletin 2005, 50, 504. [CrossRef]

${ }^{23}$ Prygiel, E.; Superville, P. J.; Dumoulin, D.; Lizon, F.; Prygiel, J.; Billon, G. On biogeochemistry and water quality of river canals in Northern France subject to daily sediment resuspension due to intense boating activities. Environmental Pollution 2015, 197, 295. [CrossRef]

${ }^{24}$ Zhang, C.; Zhi-Gang, Y.; Zeng, G.; Jiang, M.; Yang, Z.; Cui, F.; Zhu, M.; Shen, L.; Hu, L. Effects of sediment geochemical properties on heavy metal bioavailability. Environmental International 2014, 7, 270. [CrossRef]

${ }^{25}$ Harbison, P. Mangrove muds a sink and source for trace metals. Marine Pollution Bulletin 1986, 17, 273. [CrossRef]

${ }^{26}$ Soto-Jiménez, M. F.; Páez-Osuna, F. Distribution and Normalization of Heavy Metal Concentrations in Mangrove and Lagoonal Sediments from Mazatlán Harbor (SE Gulf of California). Estuarine, Coastal and Shelf Science 2001, 53, 259. [CrossRef]

${ }^{27}$ Huerta-Diaz, M. A.; Morse, J. W. Pyritization of trace metals in anoxic marine sediments. Geochimica et Cosmochimica Acta 1992, 56, 2681. [CrossRef]

${ }^{28}$ Morse, J. W.; Luther, G. W. Chemical influences on trace metal sulfide interactions in anoxic sediments. Geochimica et Cosmochimica Acta 1999, 63, 3373. [CrossRef] 